\title{
Loyalty program effectiveness: Theoretical reviews and practical proofs
}

\author{
Muhammad Alshurideh ${ }^{a^{*}}$, Anwar Gasaymeh ${ }^{\mathrm{b}}$, Gouher Ahmed ${ }^{\mathrm{c}}$, Haitham Alzoubic and \\ Barween Al Kurd ${ }^{d}$
}

${ }^{a}$ University of Sharjah, United Arab Emirates
${ }^{b}$ Applied Science Private University, Jordan
${ }^{c}$ Skyline University College, United Arab Emirates
${ }^{d}$ Amman Arab University, Jordan

\section{CH R O I C L E A B S T RAC T}

\begin{tabular}{l} 
Article history: \\
Received November 28, 2019 \\
Received in revised format \\
January 30,2020 \\
Accepted February 112020 \\
Available online \\
February 122020 \\
\hline Keywords: \\
Loyalty program \\
Benefits and rewards \\
Loyalty program aim \\
Loyalty program budget \\
Loyalty program employees \\
Target customers \\
Promotional tools
\end{tabular}

\begin{abstract}
Loyalty programs are widely used by organizations as a structured customer relationship management (CRM) tool to build and extend customer-supplier relationship. Although a large number of benefits are offered through them to both companies and consumers, loyalty programs face a set of planning and implementation pitfalls. Scholars or practitioners rarely discuss such pitfalls. Thus, this paper intends to add further values to the current literature by exploring/investigating the main loyalty scheme pitfalls, both theoretically and practically. The study explores a set of loyalty program planning problems and some of the execution's drawbacks, including clear aim need, loyalty program design, budgeting and experienced employee involvement. In addition to loyalty programs benefits and rewards offered, loyalty programs target customer selection problems using loyalty program promotional tools. For the study, 161 managers and employees who were involved in loyalty program planning and execution were surveyed. Smart-PLS was used to test the developed model and hypotheses. The study found that all studied loyalty program elements identified affected their planning and implementation. However, some of these elements where seen important to be considered when planning loyalty schemes, such schemes' benefits and rewards offered were still not planned properly and did not meet customer needs or even expectations and, in most cases, the loyalty programs' aims were not clear to all their stakeholders. The paper also provides additional discussion about additional issues of loyalty schemes planning and execution problems and proposes a set of solutions and recommendations, which might highlight some of the future venues with this regard.
\end{abstract}

(C) 2020 by the authors; license Growing Science, Canada.

\section{Introduction}

Loyalty programs have been extensively studied and widely-used as one of the main customer relationship marketing techniques to retain loyal customers, and to extend customer-supplier relationships by retaining switched customers or even to activating inactive customers (Alshurideh, 2016; Alshurideh, 2017; Alshurideh, 2014). However, the effectiveness and the obstacles of applying loyalty programs have been rarely discussed in-depth in low-to-middle economies. Loyalty programs in the Middle East are still in the initial stages of planning and adaption as one of the main customer

\footnotetext{
* Corresponding author

E-mail address: malshurideh@sharjah.ac.ae (M. Alshurideh)

(C) 2020 by the authors; licensee Growing Science.

doi: 10.5267 j.uscm.2020.2.003
} 
relationship marketing tools. However, in the United Kingdom (UK), Sainsbury's loyalty program has eight million participants and Tesco's loyalty program has 12 million customers in their club-card database. It has been claimed that the United States' (US) loyalty marketing is estimated to be around a $\$ 6$ billion industry within about 2250 different loyalty programs, and about $92 \%$ of UK customers participate in at least one loyalty program with about $78 \%$ participating in two or more loyalty programs (Berman, 2006).

Loyalty programs have been widely-researched in different business aspects, but little research with published results discuss the effectiveness of loyalty program, benefits, their uses or measurements (Lewis, 2004). As a result, loyalty programs often fail before starting their applications or have some pitfalls in their planning and implementation. It has been claimed by Rigby et al. (2003) that a five percent increase in customer retention might increase an organization's profits by $25 \%$ to $95 \%$. Thus, it has been declared that true loyalty programs should exert more investment in customers as claimed by Shugan (2005). In addition, additional investments should be exerted on other program elements such as employees, technologies and factors such as logistics that help to make loyalty programs successful. For example, technologies enable managers to handle sequence consumer software to build and strengthen relationships with the best customers (Rigby et al., 2002). Therefore, when designing loyalty programs, companies should bear in mind how to design these programs properly especially in their early application stages. Some scholars such as Ashley et al. (2011) found that some customers prefer loyalty programs that are easily accessed and used. Another important issue that drives customers to be committed to the loyalty programs is to what level that loyalty programs are easily to be accessed, easily to be registered with, create an account, used and get benefits from the accumulated purchase or use in a constant basis. As a result, organizations and their management should commit to programs with the same customer commitment levels. This is because one of the main challenges that face loyalty program success and consumer participation is that both relationship partners should be involved and committed to the process properly (Mulhern \& Duffy, 2004). As a result, both long-term and shortterm loyalty program issues need to be reviewed again.

\section{Literature: Why loyalty programs fail?}

After reviewing a large number of loyalty program studies, a set of theoretical and applicable pitfalls have been recorded, which led this article to report on the reasons for loyalty program failure. These failures have been categorized into seven factors, which are loyalty program aims, loyalty program employee and workers, loyalty program customer target, loyalty programs' budget, loyalty programs planning, loyalty program, and rewards types offered and loyalty program promotional tools used. Such factors will be explained in more detail in the following part of this paper.

\subsection{Loyalty program aims influence}

One of the main issues that needs to be highlighted is why a loyalty program should be designed and prepared. Researchers differ in explaining the aim of these programs or having a clear aim that can be translated accurately to the target market. It has been explained in different situations that the aim of the designing a loyalty program is to make the customer more loyal (Leenheer \& Bijmolt, 2008), to push customer behavior to reach a certain level (Leenheer et al., 2007), to make loyal customers receive a certain amount or type of information (Leenheer et al., 2003), to form a group of behaviorally-loyal customers (Bandyopadhyay, Gupta \& Dube, 2005), and to increase the number of customers who are solely loyal buyers to a specific brand (Sharp \& Sharp, 1997). Sometimes, loyalty programs are used as a brand extension aid (Uncles, Dowling \& Hammond, 2003), or to bring in more non-loyal members (Alshurideh, 2014; Hikkerova, 2011) or to repeat business (Omar et al., 2011). Some firms use loyalty programs to increase customer retention or even customer development (Alshurideh, 2010; Kamakura et al., 2005), while in other circumstances, they is used to increase regular customer's loyalty (Alshuridehet et al., 2017; Mimouni-Chaabane \& Volle, 2010). The use of loyalty programs to create new behavior, amend or change an existing behavior is still a dilemma and more evidence is needed to 
support these claims. To sum up, it seems that loyalty program aims are not clear for both customers and organizations' employees who are responsible for executing them, and, as a result, more effort should be given when planning loyalty programs and their interrelated incentives. Based on this explanation, the loyalty programs' aim influence can be described as:

$\mathbf{H}_{1}$ : Loyalty program aims influence its effectiveness.

\subsection{Loyalty program employee influence}

It is important to remember that planning loyalty rewards is not the only mission for which the organization is usually responsible. Other responsibilities include offering the right management and determining to what level human capabilities are required to work on planning and executing such programs. It has been claimed in different situations that loyalty programs have failed because of the employees or managers who prepare, plan or execute the programs. Sometimes these personnel lack the experience, training, and patience required when dealing with loyal customers. As human interaction behavior is important for the success of loyalty program execution, loyalty program training and education is critical (Ardts et al., 2001). Different ideas have been suggested to enhance employee productivity such as communication, satisfaction, caring, commitment and loyalty. Organization leaders were also a factor in determining the success of the loyalty program (Yukl, 2008). Employees also seem to be playing a critical role in loyalty program success, as they are needed to orient customers well, otherwise all efforts will be lost and the loyalty program will fail (Asiah et al., 2011). In different situations, it has been claimed that happy employees lead to loyal customers (Atkins et al., 1996), and having good human resource management is the key of competitive advantage when executing such programs (Noe et al., 2017). In addition, it has become known that loyal customers need better trained, skilled, experienced and even well-equipped employees to serve them better. By another means, organizations sometime need to enhance their internal service quality to serve loyal customers better (ELSamen \& Alshurideh, 2012; Heskett et al., 1994).

It is very important to remember that loyalty schemes are designed to reward loyal customers for staying longer and buying more. However, such schemes should take into consideration other partners who are involved in such scheme implications such as employees who, in turn, help in achieving the needed customer targets from implementing such programs (Ahmad \& Buttle, 2002). Based on this, one of the main issues that play a critical role in making loyalty programs successful is to compensate those marketers or sales forces who are responsible for executing such programs (Leventhal \& Zineldin, 2006). This is because the majority of loyalty programs fail to compensate those partners who should take care of executing and following-up such programs effectively. Based on this explanation, the loyalty program employee's influence can be described as:

$\mathbf{H}_{2}$ : Loyalty program employees influence its effectiveness.

\subsection{Loyalty program planning' influence}

One of the problems that contribute to loyalty programs' failure is that some of the loyalty programs have been built and planned on unrelated dimensions such as consumer demographical dimensions (for example, income or age). However, loyalty programs should be planned according to other customers' interrelated dimensions such the behavioral dimensions (for example, purchase frequency visits, purchased items, customer product-high involvement and transaction size) (Evanschitzky et al., 2012). Accordingly, studying the target customers well is an initial success stage in preparing and, in later stages, implementing the loyalty programs. In addition, it is good to remember that the majority of loyalty programs are mainly managed by consumers themselves starting from filling the initial personnel information till following the way of receiving the planned loyalty program rewards. Thus, the targeted customers play an initial role in loyalty program (LP) efficiency and success, especially when educated and leading customers know how to use such programs and employ their previous 
experiences in such use. These are considered main issues in LP success and customers' needs should be considered properly when investigating the loyalty program's effectiveness. It seems that customer types, education, ages and location affect loyalty program execution and its success or failure. According to Berman (2006), loyalty programs can be used by retailers to target special customers precisely, especially the most profitable ones. Sometimes loyalty programs are designed for a selective target to activate or drive a desired behavior by using different types of rewards, which customers redeem in a specific way (Bushold \& Shipley, 2002). One of the good loyalty programs uses is that it can be used to target customers or classified or segmented them then targeted them easily based on the loyalty program objectives (Ngai et al., 2009).

Scholars such as Kumar and Shah (2004) have identified that some loyalty programs fail because they did not encourage the potential customer to spend more money and by the end did not increase an organization's profitability by implementing loyalty programs. Thus, failing to consider customers' future purchase and repeat buying smoothly is a problem that should be considered proactively specially when loyalty programs is used to send personalized marketing messages through mobile marketing (Wegner \& Wegner, 2013). As a result, the need to target loyalty program customers can be described as:

$\mathbf{H}_{3}$ : Loyalty program planning influence its effectiveness.

\subsection{Loyalty programs' budget influence}

It has been found that in different situations, loyalty program budgets and startup costs affect developing an effective customer loyalty plan. For example, Shell spent between 20 and 40 million pounds on developing its smart card loyalty programs, and Tesco initial data gathering cost was estimated about 10 million pounds (Berman, 2006). One of the main problems that organizations face is that they plan loyalty programs as part of marketing budgets without considering a real budget for each loyalty program separately which making the process of evaluating the financial impacts of such programs and measure their returns is not an easy mission especially when e-loyalty programs planned (Smith, 2000). Another issue that can be highlighted is how organizations determine a communication budget for the planned loyalty program customers. Promoting and communicating such programs is a major part of their success, especially for loyalty cards programs (García Gómez et al., 2006). Based on this explanation, the loyalty programs' budgets influence can be described as:

$\mathbf{H}_{4}$ : Loyalty program costs (budgets) influence its effectiveness.

\subsection{Loyalty programs' targeted customers influence}

Loyalty programs preparation is an essential stage for launching loyalty programs. One of the critical preparation issues is studying and choosing the right target customers. Identifying the correct target customers helps in having more details about how to implement the loyalty program properly. This is especially important as some customers are not happy to enter into long-term relationships with suppliers, and multiple cardholders are often less likely to stay loyal nowadays (Meyer-Waarden, 2007). Some loyalty programs have been built to sell products or services that are not wanted by customers. Thus, these programs will not enable organizations to build relationships with customers who place little value on such programs (Rigby et al., 2002). Preparing customer and user minds and inspiring them to acknowledge and accept these programs and respond to them appropriately is also important (Warrick et al., 2015). To confirm this, some studies have denoted that loyal customers can advocate the loyalty programs themselves as well as the organizations or even the brands (Dowling \& Uncles, 1997). Additionally, some targeted customers are not expected to transfer to brand loyalty in most loyalty schemes cases especially when there is a low-involvement situation (Yi \& Jeon, 2003). Sometimes, the time, place and tools used do not match the customers' readiness to accept the program itself. As a result, Rehnen (2016) explains that part of the program loyalty induction strategy is 
preparing and implementing the loyalty program correctly and choosing the proper method to inform the target recipients through clear and direct campaigning. Therefore, the loyalty programs' targeted customers influence can be described as:

H5: Loyalty programs' targeted customers influences its effectiveness.

\subsection{Loyalty program and rewards offered influence}

One of the main questions that organizations need to answer carefully and plan well for when designing loyalty programs is the type of rewards and incentives their customers prefer (Jang \& Mattila, 2005). These incentives are important and need to be identified as they usually attract customer attention, and are seen as important from the customer's perspective. In addition, they encourage customers to enroll in loyalty programs and sign long-term contracts with suppliers easily (Al Dmour et al., 2014; Alshurideh, 2017; Alshurideh, 2016a). This is especially so when customers feel that the rewards are planned according to their needs (Alshurideh, 2014). As a result, loyalty programs should be planned and adopted to satisfy different customer need types (Alshurideh, 2019; Dowling \& Uncles, 1997).

Many scholars have linked customer loyalty and customer involvement (Al-dweeri et al., 2017; Skogland \& Siguaw, 2004). Therefore, special care should be exerted when planning the reward types that should be delivered to meet customer needs, preferences and involvement. The better-planned loyalty programs that fit high-involvement products and services, the better customer reactions will be. On the other hand, with low involvement products and services, customer reactions towards loyalty programs will be negative (for example, loyalty membership clubs) (Curasi \& Kennedy, 2002). This is because the effectiveness and value of loyalty programs usually differ based on the customer's involvement and even the customer's perception of the values delivered (Yi \& Jeon, 2003). The same issue applies to customer experience (Alshurideh, Nicholson \& Xiao, 2012). Customer experience is highly-important with loyalty programs, because the more customers experience the benefits that loyalty programs offer positively, the greater will be the customer's purchase repetition rate, as well as customer acceptance, interaction, purchasing and repeat purchasing behavior (Alshurideh et al., 2012; Verhoef et al., 2009).

Scholars such as Hennessy and Safran (1999) identified that loyalty programs failed because customers experienced difficulties when redeeming loyalty program incentives, especially those that provided incentives in different situations or the purchasing of products/services that were offered by other organizations rather than the merchants who provided them. Therefore, the loyalty program rewards and benefits influence can be described as:

H6: Loyalty program incentives and benefit types offered influence its effectiveness

\subsection{Loyalty program and promotional tools used influence}

According to Yi and Jeon (2003), loyalty programs should be treated differently and not the same as other promotional tools such as price discount. This is because loyalty programs usually adopt a variety of approaches to shape, maintain or change consumer behavior with a long-term perspective. Loyalty program promotion plays a critical role in its success, especially those that are related directly to payment transactions (Powell, 2009). As a result, it is essential that the platforms that are used to promote loyalty programs are planned effectively (Fordyce, Patel \& Shepard, 2013), especially programs promoted through manufacturers, supply chains, distributors or merchants. However, it is not just the type of loyalty program promotional tool that affects its performance and output, but also the duration of the promotion within the loyalty program, the value of the promotion and the loyalty program rules (Fordyce \& Suarez, 2008). In addition, organizations should use loyalty program promotional tools that increase customer reactions, especially if the promotion is planned to be within a limited period of time or to sell a specific number of products (Alshurideh, 2016b; Kivetz, 2005). Pritchard and Negro (2001) confirm this issue and claim that some loyalty programs, for example, sport 
loyalty programs, fail because they were marketed using traditional methods and/or applied classical approaches. The issue is not just related to the way the loyalty program was executed, but the structure of the program is a concern. According to Dreze and Nunes (2008), some loyalty programs fail because they have problems in their structure specially the promotional part, which result in customers failing to perceive them correctly. For this reason, the influence of loyalty program promotional tools can be described as:

$\mathbf{H}_{7}$ : Loyalty program promotional tools influence its effectiveness.

\section{Study model and hypotheses}

Fig. 1 illustrates the study's model that summarizes the main study factors.

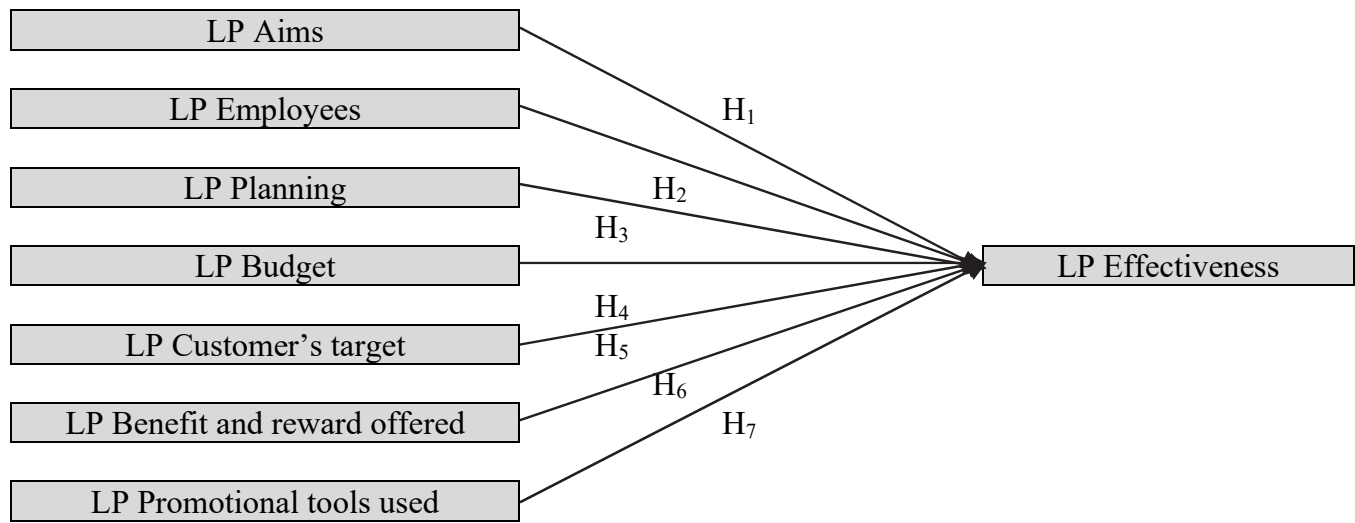

Fig. 1. Model of the study

\section{Study data collection method}

The study aimed at finding the main loyalty program planning determinants. By reviewing the literature, a large number of loyalty program planning factors and execution platforms were determined. Then these factors were categorized based on frequencies. The main factors were then chosen to be tested practically using the study's model. Seven elements were selected, namely, loyalty program aims, budget, planning, employees, rewards offered, customers targeted and promotional tools used. For the study, a quantitative research approach was used to collect the primary data, and 178 participants were chosen to be surveyed. The population target was all those who were involved directly or directly in loyalty program preparing, designing, executing and evaluating. From the data collection, 161 questionnaires were analyzed. As it was very difficult to determine the population, a convenience sampling method was employed.

\section{Findings and Discussion}

For testing the suitability of the study data and model, construct measurement and assessment of the measurement model will be checked.

\subsection{Construct Measurement}

In the analysis of the collected data, the two-step analytical procedure was followed (Anderson \& Gerbing, 1988). First, the measurement model was examined for its reliability, convergent validity and discriminant validity. Second, the structural model was examined for its strength and the relationship directions within the theoretical constructs. Structural equation modelling was adopted to test the causeand-effect relations within the constructs in the research model, with the partial least square method used as the analysis tool. The Smart PLS 3.0 software package, which was developed by Ringle et al. (2005) was used to analyze the data. . The use of SmartPLS for the Partial Least Squares-Structural Equation Modeling (PLS-SEM), a software developed by Ringle et al. (2005), was quite prevalent. In this study, the PLS-SEM was used to assess the measurement and structural models. The association 
between the indicators refers to the measurement model (outer model), whereas the association between the latent constructs refers to the structural model. To measure the proposed model, SEM-PLS was used (Anderson \& Gerbing, 1988), with the greatest probability method.

A number of measurements were conducted that consisted of factor loadings, average variance extracted (AVE) and composite reliability (CR) to determine reliability and convergent validity. To demonstrate the weight and correlation value of every questionnaire variable as a perceived indicator, factor loadings were employed, whereas bigger load value could help in the representation of the factors' dimensionality. To measure reliability, the composite reliability (CR) measure was used. The purpose of $\mathrm{CR}$ is similar as it offers a precise value by employing factor loadings in the constructed formula. average variance extracted (AVE) refers to the average quantity of variance in the given variable, which explains the latent construct. When the discriminate validity is greater than one factor, AVE can be employed to analyze the convergence of every factor. As is evident from Table 1, the experiment consequence for the questionnaire reliability and convergent validity exceeded the condition for the reliability and convergent validity. An outline of the reliability and validity of the questionnaire is shown in Table 1, with the analysis finding for every factor by presenting the variable obtained from the questionnaire.

\subsection{Assessment of the measurement model (outer model)}

For the assessment of the measurement model, convergent validity and discriminate validity will be checked.

\subsubsection{Convergent validity}

Following Hair, Black, Babin, Anderson and Tatham (1998), factor loadings, variance extracted and reliability (consisting of Cronbach's Alpha and composite reliability) as indicators were used to estimate the relative amount of convergent validity. The reliability coefficient and composite reliability (CR) for all of constructs exceeded 0.7 , indicating internal consistency between multiple measurements of a construct (Hair et al., 1998). As shown in Table 1, Cronbach's alpha scores exceeded the acceptable value of 0.7 (Gefen, Straub \& Boudreau, 2000; Nunnally \& Bernstein, 1978), and composite reliabilities of constructs ranged from 0.723 to 0.875 . In addition, all average variance extracted (AVE) values, ranging from 0.569 to 0.874 , satisfied the criterion of explaining at least $50 \%$ of variance extracted among a set of items (Falk \& Miller, 1992) underlying the latent construct. As a result, the scales for evaluating the constructs were deemed to achieve convergent validity.

\subsubsection{Discriminate validity}

As seen in Table 1, the requirements of discriminant validity were satisfied since all AVE values were greater than the squared correlation between the constructs in the measurement model. It is recommended that the construct finds a minimum of $50 \%$ of the measurement variance when the AVE value is more than 0.5. Partial Least Squares (Smart PLS 3.0) were used to evaluate the discriminate value. Table 3 includes the loadings and cross-loadings. Based on the depth analysis of the loadings and cross-loadings, it was demonstrated that the measurement items were all loaded broadly on their own latent constructs instead of loading on other constructs. Table 2 includes the AVE analysis. The bold diagonal elements in the table demonstrate the square root of the AVE scores. Conversely, the offload diagonal elements signified the correlations between the constructs. Table 2 clearly shows that the square root of the AVE values lay in the range of 0.769 to 0.903 , which was higher in comparison to the suggested value of 0.5 . The AVE was empirically higher compared to any correlations with the construct. For every construct, it clearly referred to a greater variance of all constructs with their own measures rather than other constructs in the model, which supported the discriminate validity. In accordance with this issue, Gefen and Straub (2000) agree that the second condition of discriminant validity could be explained properly. The loading of every item must be higher when compared to the loading of its equivalent variable. Hence, it is evident from Table 4 that the second criterion was also 
fulfilled. The third condition of discriminant validity is that the values of HTMT must be less than 0.85 . It is evident from Table 5 that the third criterion was also confirmed, and, as a result, discriminant validity was established.

\section{Table 1}

Convergent validity results which assures acceptable values (Factor loading, Cronbach's Alpha, composite reliability $\geq 0.70 \&$ AVE $>0.5$ )

\begin{tabular}{|c|c|c|c|c|c|}
\hline Constructs & Items & Factor Loading & Cronbach's Alpha & $\mathrm{CR}$ & AVE \\
\hline \multirow[t]{4}{*}{ LP Aims } & LP_AIM1 & 0.785 & \multirow{4}{*}{0.874} & \multirow{4}{*}{0.723} & \multirow{4}{*}{0.631} \\
\hline & LP_AIM2 & 0.863 & & & \\
\hline & LP_AIM3 & 0.728 & & & \\
\hline & LP_AIM4 & 0.911 & & & \\
\hline \multirow[t]{4}{*}{ LP Benefits and rewards offered } & LP_BEN1 & 0.778 & \multirow{4}{*}{0.724} & \multirow{4}{*}{0.746} & \multirow{4}{*}{0.574} \\
\hline & LP_BEN2 & 0.866 & & & \\
\hline & LP_BEN3 & 0.819 & & & \\
\hline & LP_BEN4 & 0.779 & & & \\
\hline \multirow[t]{4}{*}{ LP Budget } & LP_BUD1 & 0.889 & \multirow{4}{*}{0.787} & \multirow{4}{*}{0.733} & \multirow{4}{*}{0.569} \\
\hline & LP_BUD2 & 0.735 & & & \\
\hline & LP_BUD3 & 0.829 & & & \\
\hline & LP BUD4 & 0.777 & & & \\
\hline \multirow[t]{4}{*}{ LP Customer target } & LP_CUS1 & 0.755 & \multirow{4}{*}{0.879} & \multirow{4}{*}{0.875} & \multirow{4}{*}{0.715} \\
\hline & LP_CUS2 & 0.853 & & & \\
\hline & LP_CUS3 & 0.721 & & & \\
\hline & LP_CUS4 & 0.818 & & & \\
\hline \multirow[t]{3}{*}{ LP Effectiveness } & LP_EFF1 & 0.871 & \multirow{3}{*}{0.814} & \multirow{3}{*}{0.844} & \multirow{3}{*}{0.721} \\
\hline & LP_EFF2 & 0.787 & & & \\
\hline & LP_EFF3 & 0.811 & & & \\
\hline \multirow[t]{4}{*}{ LP Employees } & LP_EMP1 & 0.930 & \multirow{4}{*}{0.799} & \multirow{4}{*}{0.800} & \multirow{4}{*}{0.874} \\
\hline & LP_EMP2 & 0.867 & & & \\
\hline & LP_EMP3 & 0.745 & & & \\
\hline & LP EMP4 & 0.747 & & & \\
\hline \multirow[t]{4}{*}{ LP Promotional tools used } & LP_PRO1 & 0.730 & \multirow{4}{*}{0.709} & \multirow{4}{*}{0.842} & \multirow{4}{*}{0.846} \\
\hline & LP_PRO2 & 0.758 & & & \\
\hline & LP_PRO3 & 0.801 & & & \\
\hline & LP PRO4 & 0.859 & & & \\
\hline \multirow[t]{4}{*}{ LP Planning } & LP_PLA1 & 0.755 & \multirow{4}{*}{0.771} & & \\
\hline & LP_PLA2 & 0.760 & & 708 & 0680 \\
\hline & LP_PLA3 & 0.763 & & 0.198 & 0.689 \\
\hline & LP_PLA4 & 0.818 & & & \\
\hline
\end{tabular}

Table 2

Fornell-Larcker Scale

\begin{tabular}{|c|c|c|c|c|c|c|c|c|}
\hline & LP_AIM & LP_BEN & LP_BUD & LP_CUS & LP_EFF & LP_EMP & LP_PRO & LP_PLA \\
\hline LP_AIM & 0.844 & & & & & & & \\
\hline LP_BEN & 0.278 & 0.879 & & & & & & \\
\hline LP_BUD & 0.268 & 0.602 & 0.795 & & & & & \\
\hline LP_CUS & 0.389 & 0.298 & 0.319 & 0.827 & & & & \\
\hline LP_EFF & 0.158 & 0.226 & 0.598 & 0.574 & 0.815 & & & \\
\hline LP_EMP & 0.328 & 0.550 & 0.657 & 0.454 & 0.551 & 0.873 & & \\
\hline LP_PRO & 0.287 & 0.627 & 0.399 & 0.589 & 0.320 & 0.625 & 0.903 & \\
\hline LP_PLA & 0.189 & 0.111 & 0.287 & 0.251 & 0.580 & 0.668 & 0.398 & 0.769 \\
\hline
\end{tabular}

\subsection{Assessment of structural model (Inner model)}

For the assessment of the structural model, Coefficient of determination and Structural Model Analysis will be used.

\subsubsection{Coefficient of determination $-R^{2}$}

The structural model is typically inspected utilizing the coefficient of determination $\left(\mathrm{R}^{2}\right.$ value $)$ measure (Dreheeb et al., 2016). This coefficient is formed to measure the predictive accuracy of the model and is processed as the squared correlation between a specific endogenous construct's actual and predicted values (Hair et al., 2016; Senapathi \& Srinivasan, 2014). The exogenous latent variables combined 
effect on an endogenous latent variable is connoted by the coefficient. The coefficient is the squared correlation between the actual and predicted values of the variables, hereafter, it adds the additional meaning of variance-degree in the endogenous constructs. This fact is defended by each exogenous construct and it helps in identifying it.

Table 3

Cross-loading results

\begin{tabular}{|c|c|c|c|c|c|c|c|c|}
\hline & LP_AIM & LP_BEN & LP_BUD & LP_CUS & LP_EFF & LP_EMP & LP_PRO & LP_PLA \\
\hline LP_AIM1 & 0.785 & 0.123 & 0.571 & 0.171 & 0.470 & 0.279 & 0.276 & 0.272 \\
\hline LP AIM2 & 0.863 & 0.525 & 0.343 & 0.433 & 0.353 & 0.265 & 0.255 & 0.286 \\
\hline LP_AIM3 & 0.728 & 0.368 & 0.181 & 0.184 & 0.288 & 0.223 & 0.358 & 0.417 \\
\hline LP_AIM4 & 0.911 & 0.687 & 0.422 & 0.382 & 0.326 & 0.282 & 0.398 & 0.424 \\
\hline LP_BEN1 & 0.252 & 0.778 & 0.239 & 0.228 & 0.399 & 0.288 & 0.366 & 0.523 \\
\hline LP_BEN2 & 0.394 & 0.866 & 0.138 & 0.228 & 0.332 & 0.274 & 0.386 & 0.511 \\
\hline LP_BEN3 & 0.436 & 0.819 & 0.461 & 0.122 & 0.125 & 0.277 & 0.381 & 0.466 \\
\hline LP_BEN4 & 0.321 & 0.779 & 0.178 & 0.433 & 0.522 & 0.267 & 0.378 & 0.400 \\
\hline LP_BUD1 & 0.275 & 0.112 & 0.889 & 0.644 & 0.408 & 0.273 & 0.379 & 0.404 \\
\hline LP_BUD2 & 0.423 & 0.433 & 0.735 & 0.242 & 0.120 & 0.227 & 0.376 & 0.491 \\
\hline LP BUD3 & 0.431 & 0.444 & 0.829 & 0.399 & 0.433 & 0.233 & 0.245 & 0.221 \\
\hline LP_BUD4 & 0.427 & 0.346 & 0.777 & 0.222 & 0.183 & 0.288 & 0.230 & 0.245 \\
\hline LP_CUS1 & 0.346 & 0.394 & 0.417 & 0.755 & 0.212 & 0.118 & 0.230 & 0.245 \\
\hline LP_CUS2 & 0.214 & 0.557 & 0.522 & 0.853 & 0.296 & 0.201 & 0.233 & 0.249 \\
\hline LP_CUS3 & 0.289 & 0.245 & 0.312 & 0.721 & 0.226 & 0.293 & 0.246 & 0.263 \\
\hline LP_CUS4 & 0.377 & 0.286 & 0.272 & 0.818 & 0.428 & 0.421 & 0.119 & 0.177 \\
\hline LP_EFF1 & 0.159 & 0.325 & 0.209 & 0.289 & 0.871 & 0.467 & 0.220 & 0.266 \\
\hline LP_EFF2 & 0.289 & 0.289 & 0.268 & 0.411 & 0.787 & 0.433 & 0.330 & 0.337 \\
\hline LP_EFF3 & 0.396 & 0.274 & 0.356 & 0.329 & 0.811 & 0.340 & 0.215 & 0.267 \\
\hline LP_EMP1 & 0.375 & 0.417 & 0.387 & 0.406 & 0.545 & 0.930 & 0.225 & 0.207 \\
\hline LP_EMP2 & 0.252 & 0.170 & 0.284 & 0.433 & 0.200 & 0.867 & 0.186 & 0.194 \\
\hline LP_EMP3 & 0.255 & 0.187 & 0.234 & 0.436 & 0.397 & 0.745 & 0.265 & 0.336 \\
\hline LP_EMP4 & 0.379 & 0.266 & 0.234 & 0.309 & 0.361 & 0.747 & 0.311 & 0.284 \\
\hline LP_PRO1 & 0.145 & 0.257 & 0.188 & 0.205 & 0.279 & 0.284 & 0.730 & 0.288 \\
\hline LP_PRO2 & 0.193 & 0.235 & 0.300 & 0.319 & 0.252 & 0.315 & 0.758 & 0.349 \\
\hline LP_PRO3 & 0.246 & 0.362 & 0.219 & 0.225 & 0.263 & 0.296 & 0.801 & 0.296 \\
\hline LP_PRO4 & 0.313 & 0.224 & 0.180 & 0.402 & 0.385 & 0.229 & 0.859 & 0.232 \\
\hline LP_PLA1 & 0.375 & 0.290 & 0.253 & 0.334 & 0.285 & 0.313 & 0.371 & 0.755 \\
\hline LP_PLA2 & 0.255 & 0.170 & 0.299 & 0.437 & 0.373 & 0.224 & 0.290 & 0.760 \\
\hline LP PLA3 & 0.253 & 0.187 & 0.208 & 0.439 & 0.395 & 0.188 & 0.253 & 0.763 \\
\hline LP_PLA4 & 0.377 & 0.266 & 0.204 & 0.329 & 0.360 & 0.402 & 0.334 & 0.818 \\
\hline
\end{tabular}

Table 4

Heterotrait-Monotrait Ratio (HTMT)

\begin{tabular}{|c|c|c|c|c|c|c|c|c|}
\hline & LP_AIM & LP_BEN & LP_BUD & LP_CUS & LP_EFF & LP_EMP & LP PRO & LP_PLA \\
\hline \multicolumn{9}{|l|}{ LP_AIM } \\
\hline LP_BEN & 0.332 & & & & & & & \\
\hline LP_BUD & 0.419 & 0.605 & & & & & & \\
\hline LP_CUS & 0.328 & 0.522 & 0.458 & & & & & \\
\hline LP_EFF & 0.280 & 0.267 & 0.470 & 0.571 & & & & \\
\hline LP_EMP & 0.701 & 0.685 & 0.597 & 0.344 & 0.637 & & & \\
\hline LP_PRO & 0.607 & 0.587 & 0.489 & 0.362 & 0.227 & 0.334 & & \\
\hline LP_PLA & 0.128 & 0.588 & 0.217 & 0.447 & 0.227 & 0.638 & 0.639 & \\
\hline
\end{tabular}

As stated by Chin (1998), whenever the value is more than 0.67 , it is seen as high, and this implies that the qualities in the scope of 0.33 to 0.67 are direct and the qualities in the scope of 0.19 to 0.33 are weak values. Furthermore, when the estimation is lower than 0.19 , it is inadmissible. In Table 5 and Fig. 2, it can be seen that the model had a high predictive power, which supported almost $74 \%$ of the variance in the LP Effectiveness. 
Table 5

$\mathrm{R}^{2}$ of the endogenous latent variables

\begin{tabular}{lccc}
\hline & Constructs & $\mathbf{R}^{\mathbf{2}}$ & Results \\
\hline LP Effectiveness & & 0.739 & High \\
\hline
\end{tabular}

\subsubsection{Structural Model Analysis}

The proposed hypotheses could be tested by using a structural model with SEM-PLS (Salloum \& Shaalan, 2018) with the highest likelihood estimation, so that the associations between the theoretical constructs for the structural model could be examined (Salloum et al., 2018; Salloum \& Shaalan, 2018). Table 5 and Fig. 2 present an outline of the outcomes, and it can be seen that all hypotheses were significant. Based on the data analysis hypotheses, H1, H2, H3, H4, H5, H6 and H7 were supported by the empirical data. The results showed that LP Effectiveness (LP_EFF) significantly influenced LP Aims (LP_AIM) $(\beta=0.587, \mathrm{P}<0.001)$, LP Employees (LP_EMP) $(\beta=0.248, \mathrm{P}<0.05)$, LP Planning (LP_PLA) $(\beta=0.579, \mathrm{P}<0.001)$, LP Budget (LP_BUD) $(\bar{\beta}=0.439, \mathrm{P}<0.001)$, LP Customer target (LP_CUS) $(\beta=0.187, \mathrm{P}<0.05)$, LP Benefits and rewards offered (LP_BEN) $(\beta=0.631, \mathrm{P}<0.01)$, and LP Promotional tools used (LP_PRO) $(\beta=0.259, \mathrm{P}<0.05)$, which supported hypotheses H1, H2, H3, H4, H5, H6 and H7, respectively. A summary of the hypotheses testing results is shown in Table 6.

Table 6

Results of structural Model - Research Hypotheses Significant at $\left.\mathrm{p}^{* *}=<0.01, \mathrm{p}^{*}<0.05\right)$

\begin{tabular}{|c|c|c|c|c|c|c|}
\hline $\mathrm{H}$ & Relationship & Path & $t$-value & $p$-value & Direction & Decision \\
\hline $\mathrm{H}_{1}$ & LP Aims $\rightarrow$ LP Effectiveness & 0.587 & 12.880 & 0.004 & Positive & Supported** \\
\hline $\mathrm{H}_{2}$ & LP Employees $\rightarrow$ LP Effectiveness & 0.248 & 5.205 & 0.022 & Positive & Supported* \\
\hline $\mathrm{H}_{3}$ & LP Planning $\rightarrow$ LP Effectiveness & 0.579 & 18.468 & 0.000 & Positive & Supported** \\
\hline $\mathrm{H}_{4}$ & LP Budget $\rightarrow$ LP Effectiveness & 0.439 & 17.878 & 0.000 & Positive & Supported** \\
\hline $\mathrm{H}_{5}$ & LP Customers target $\rightarrow$ LP Effectiveness & 0.187 & 4.418 & 0.029 & Positive & Supported* \\
\hline $\mathrm{H}_{6}$ & LP Benefits and rewards offered $\rightarrow$ LP Effectivene & 0.631 & 13.489 & 0.005 & Positive & Supported $* *$ \\
\hline $\mathrm{H}_{7}$ & LP Promotional tools used $\rightarrow$ LP Effectiveness & 0.259 & 5.104 & 0.032 & Positive & Supported* \\
\hline
\end{tabular}

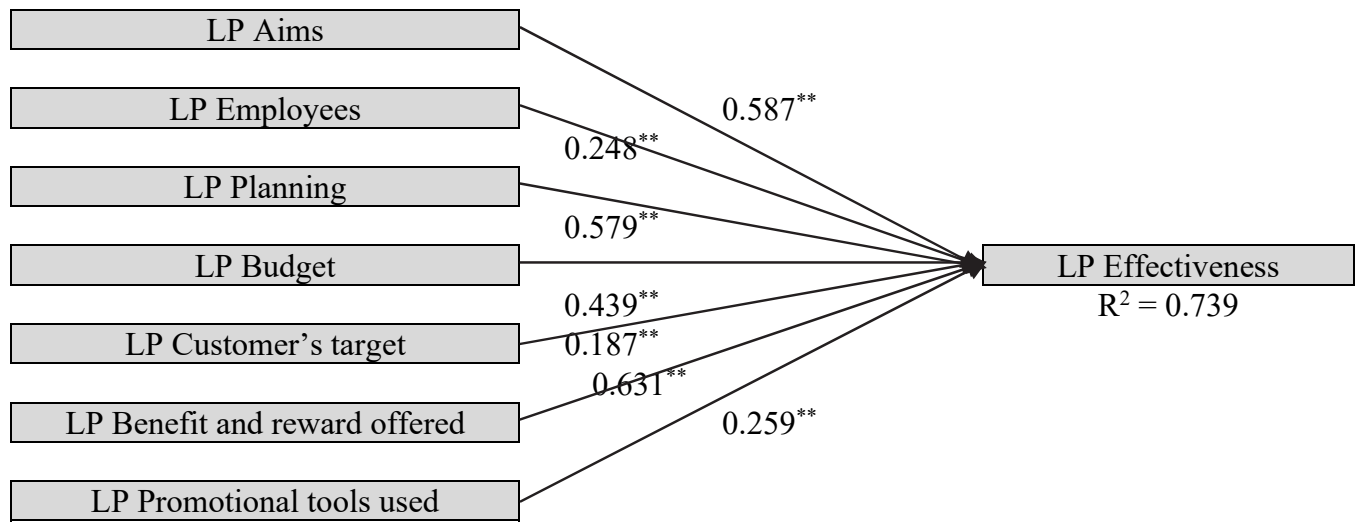

Fig. 2. Path coefficient results (significant at $\mathrm{p}^{* *}<=0.01, \mathrm{p}^{*}<0.05$ )

\section{Discussion, Conclusion and Future Recommendations}

This study provides answers for a set of questions that have rarely been discussed in previous studies. This study also provides guidelines for loyalty program applications and the main defaults that companies might face when preparing, designing, offering and controlling loyalty program execution effectively. The study found that the main factors affecting loyalty program effectiveness was the type and quality of loyalty program benefits and rewards offered, loyalty program planning, planned loyalty programs with clear objectives, followed by determining of a suitable budget for loyalty program execution. It is too important to not care about the benefits gained from a purchase or conditions that 
push customers to be involved in long-term relationships, especially those benefits aimed at creating new behavior or amending an existing behavior (Al Kurdi, 2016; Alshurideh, 2010). The type and quality of benefits offered are essential for loyalty program application, and these should be sufficient to push customers to buy and continue buying, especially in the later application stages. This ensures to what level that accumulated loyalty program use, within the time, will confirm the commitment of users. Also, multi-benefit frameworks, for example, exploration, monetary saving, social benefits, recognition and entertainment, help to ensure that customers are committed to such schemes (MimouniChaabane \& Volle, 2010). This might also help organizations to create an emotionally-loyal customer base (Kandampully et al., 2015). Based on this, the timing of benefits offered is crucial, and this was confirmed by the study's results, which found that loyalty program planning was the cornerstone of successful loyal program applications. In addition, it was, especially important to have a clear objective before application supported by a suitable source of funding to secure a good start and the continued offering of such schemes. This is because good loyalty program planning and analytics help in executing the schemes successfully within a set of clear steps (Berman, 2006). Planning also assists in finding a set of processes and methodological deficiencies, which might help in better implementation and avoidance of previous mistakes in new program launching (Banasiewicz, 2005). When considering the main issues that cause loyalty programs to fail, it is important to explain how to avoid them, and rather push loyal and non-loyal customers to join loyalty programs easily. As a result, a set of techniques have been recommended from both theoretical and practical perspectives regarding loyalty programs application problems. One of the main issues that affect loyalty program effectiveness is how to measure the effectiveness of these incentive programs, and get benefits from their applications. This issue is confirmed by Meyer-Waarden (2007) who consistently found that organization's loyalty program effects were difficult to measure. Dowling and Uncles (1997) also posed the challenging question of whether loyalty programs created extra loyalty. Although there is evidence that loyalty programs increase sales, customer visits, purchase volume and enhanced share-of-wallet, it needs to be checked whether loyalty programs generate extra loyalty, which is a new research angle that needs to be studied. Another question that might be asked is whether loyalty programs, which target customer awareness and adoption are able to create new behavior or amend an existing behavior (Alshurideh et al., 2018; Alshurideh et al., 2014; Ammari et al., 2017). One of the critical problems that make customers reluctant to enroll in loyalty programs is the loyalty program themselves (Wendlandt \& Schrader, 2007). This is because loyalty program planning includes a variety of dimensions such as economic, socio-psychological and contractual bonds. The majority of loyalty programs are planned to deliver the economic incentives and ignore the other dimensions. Thus, it is important to study other loyalty program factors not included in this study such as the effect of social bonds in addition to economical bonds to attract customers, which might help in minimizing the reluctance of targeted customers to be involved in long-term relationships with suppliers especially when using loyalty programs as a mean of relationship.

\section{References}

Ahmad, R., \& Buttle, F. (2002). Customer retention management: A reflection of theory and practice. Marketing Intelligence \& Planning, 20(3), 149-161.

Al-dweeri, R. M., Obeidat, Z. M., Al-dwiry, M. A., Alshurideh, M. T., \& Alhorani, A. M. (2017). The impact of e-service quality and e-loyalty on online shopping: moderating effect of e-satisfaction and e-trust. International Journal of Marketing Studies, 9(2), 92-103.

Al Dmour, H., Alshurideh, M., \& Shishan, F. (2014). The influence of mobile application quality and attributes on the continuance intention of mobile shopping. Life Science Journal, 11(10), 172-181.

AL KURDI, B. (2016). Healthy-Food Choice and Purchasing Behaviour Analysis: An Exploratory Study of Families in the UK. Durham University.

Alshurideh, M., Al Kurdi, B., Abumari, A., and Salloum, S. (2018). Pharmaceutical Promotion Tools Effect on Physician's Adoption of Medicine Prescribing: Evidence from Jordan. Modern Applied Science, 12(11), 210 222.

Alshurideh, D. M. (2019). Do electronic loyalty programs still drive customer choice and repeat purchase 
behaviour? International Journal of Electronic Customer Relationship Management, 12(1), 40-57.

Alshurideh, M. (2010). Customer service retention-A behavioural perspective of the UK mobile market. Durham University.

Alshurideh, M, Nicholson, M., \& Xiao, S. (2012). The effect of previous experience on mobile subscribers' repeat purchase behaviour. European Journal of Social Sciences, 30(3), 366-376.

Alshurideh, M T. (2017). A theoretical perspective of contract and contractual customer-supplier relationship in the mobile phone service sector. International Journal of Business and Management, 12(7), 201-210.

Alshurideh, Muhammad. (2016). Scope of Customer Retention Problem in the Mobile Phone Sector: A Theoretical Perspective. Journal of Marketing and Consumer Research, 20, 64-69.

Alshurideh, Muhammad, Masa'deh, R., \& Alkurdi, B. (2012). The effect of customer satisfaction upon customer retention in the Jordanian mobile market: An empirical investigation. European Journal of Economics, Finance and Administrative Sciences, 47(12), 69-78.

Alshurideh, Muhammad Turki. (2014). A qualitative analysis of customer repeat purchase behaviour in the UK mobile phone market. Journal of Management Research, 6(1), 109.

Alshurideh, Muhammad Turki. (2016a). Exploring the main factors affecting consumer choice of mobile phone service provider contracts. International Journal of Communications, Network and System Sciences, 9(12), $563-581$.

Alshurideh, Muhammad Turki. (2016b). Is customer retention beneficial for customers: A conceptual background. Journal of Research in Marketing, 5(3), 382-389.

Alshurideh, Muhammad Turki. (2017). The Impact Of Islamic Bank's Service Quality Perception On Jordanian Customer's Loyalty. Jounal of Management Reseach, 9.

Alshurideh, Muhammad Turki, Shaltoni, A. M., \& Hijawi, D. S. (2014). Marketing communications role in shaping consumer awareness of cause-related marketing campaigns. International Journal of Marketing Studies, 6(2), 163.

Ammari, G., Alkurdi, B., Alshurideh, A., \& Alrowwad, A. (2017). Investigating the impact of communication satisfaction on organizational commitment: a practical approach to increase employees' loyalty. International Journal of Marketing Studies, 9(2), 113-133.

Anderson, J. C., \& Gerbing, D. W. (1988). Structural equation modeling in practice: A review and recommended two-step approach. Psychological Bulletin, 103(3), 411.

Ardts, J., Jansen, P., \& van der Velde, M. (2001). The breaking in of new employees: effectiveness of socialisation tactics and personnel instruments. Journal of Management Development, 20(2), 159-167.

Ashley, C., Noble, S. M., Donthu, N., \& Lemon, K. N. (2011). Why customers won't relate: Obstacles to relationship marketing engagement. Journal of Business Research, 64(7), 749-756.

Asiah Omar, N., \& Musa, R. (2011). Measuring service quality in retail loyalty programmes (LPSQual) Implications for retailers' retention strategies. International Journal of Retail \& Distribution Management, 39(10), 759-784.

Atkins, P. M., Marshall, B. S., \& Javalgi, R. G. (1996). Happy employees lead to loyal patients. Marketing Health Services, 16(4), 14.

Banasiewicz, A. (2005). Loyalty program planning and analytics. Journal of Consumer Marketing, 22(6), 332339.

Bandyopadhyay, S., Gupta, K., \& Dube, L. (2005). Does brand loyalty influence double jeopardy? A theoretical and empirical study. Journal of Product \& Brand Management, 14(7), 414-423.

Berman, B. (2006). Developing an effective customer loyalty program. California Management Review, 49(1), $123-148$.

Bushold, T., \& Shipley, M. (2002, September 5). System and method for implementing a loyalty program incorporating on-line and off-line transactions. Google Patents.

Chin, W. W. (1998). The partial least squares approach to structural equation modeling. Modern Methods for Business Research, 295(2), 295-336.

Dowling, G. R., \& Uncles, M. (1997). Do customer loyalty programs really work? Sloan Management Review, $38,71-82$.

Dreheeb, A. E., Basir, N., \& Fabil, N. (2016). Impact of System Quality on Users' Satisfaction in Continuation of the Use of e-Learning System. International Journal of E-Education, e-Business, e-Management and eLearning, 6(1), 13.

Dreze, X., \& Nunes, J. C. (2008). Feeling superior: The impact of loyalty program structure on consumers' perceptions of status. Journal of Consumer Research, 35(6), 890-905.

ELSamen, A. A., \& Alshurideh, M. (2012). The impact of internal marketing on internal service quality: A case study in a Jordanian pharmaceutical company. International Journal of Business and Management, 7(19), 
84.

Evanschitzky, H., Ramaseshan, B., Woisetschläger, D. M., Richelsen, V., Blut, M., \& Backhaus, C. (2012). Consequences of customer loyalty to the loyalty program and to the company. Journal of the Academy of Marketing Science, 40(5), 625-638.

Falk, R. F., \& Miller, N. B. (1992). A primer for soft modeling. University of Akron Press.

Folkman Curasi, C., \& Norman Kennedy, K. (2002). From prisoners to apostles: a typology of repeat buyers and loyal customers in service businesses. Journal of Services Marketing, 16(4), 322-341.

Fordyce, E. W., \& Suarez, S. P. (2008, September 18). Loyalty program for merchant inventory. Google Patents.

Fordyce III, E. W., Patel, K. H., \& Shepard, D. C. (2013, December 31). Loyalty program incentive determination. Google Patents.

García Gómez, B., Gutiérrez Arranz, A., \& Gutiérrez Cillán, J. (2006). The role of loyalty programs in behavioral and affective loyalty. Journal of Consumer Marketing, 23(7), 387-396.

Gefen, D., Straub, D., \& Boudreau, M.-C. (2000). Structural equation modeling and regression: Guidelines for research practice. Communications of the Association for Information Systems, 4(1), 7.

Gefen, D., \& Straub, D. W. (2000). The relative importance of perceived ease of use in IS adoption: A study of e-commerce adoption. Journal of the Association for Information Systems, 1(1), 8.

Hair, J. F., Black, W. C., Babin, B. J., Anderson, R. E., \& Tatham, R. L. (1998). Multivariate data analysis (Vol. 5). Prentice hall Upper Saddle River, NJ.

Hair Jr, J. F., Hult, G. T. M., Ringle, C., \& Sarstedt, M. (2016). A primer on partial least squares structural equation modeling (PLS-SEM). Sage Publications.

Hennessy, L., \& Safran, S. L. (1999, November 23). Subscriber reward method. Google Patents.

Heskett, J. L., Jones, T. O., Loveman, G. W., Sasser, W. E., \& Schlesinger, L. A. (1994). Putting the serviceprofit chain to work. Harvard Business Review, 72(2), 164-174.

Hikkerova, L. (2011). The effectiveness of loyalty programs: an application in the hospitality industry. International Journal of Business, 16(2), 150.

Jang, D., \& Mattila, A. S. (2005). An examination of restaurant loyalty programs: what kinds of rewards do customers prefer? International Journal of Contemporary Hospitality Management, 17(5), 402-408.

Kamakura, W., Mela, C. F., Ansari, A., Bodapati, A., Fader, P., Iyengar, R., ... Verhoef, P. C. (2005). Choice models and customer relationship management. Marketing Letters, 16(3-4), 279-291.

Kandampully, J., Zhang, T., \& Bilgihan, A. (2015). Customer loyalty: a review and future directions with a special focus on the hospitality industry. International Journal of Contemporary Hospitality Management, 27(3), 379-414.

Kivetz, R. (2005). Promotion reactance: The role of effort-reward congruity. Journal of Consumer Research, $31(4), 725-736$.

Kumar, V., \& Shah, D. (2004). Building and sustaining profitable customer loyalty for the 21 st century. Journal of Retailing, 80(4), 317-329.

Leenheer, J., \& Bijmolt, T. H. A. (2008). Which retailers adopt a loyalty program? An empirical study. Journal of Retailing and Consumer Services, 15(6), 429-442.

Leenheer, J., Bijmolt, T. H. A., Van Heerde, H. J., \& Smidts, A. (2003). Do loyalty programs enhance behavioral loyalty? A market-wide analysis accounting for endogeneity. International Journal of Research in Marketing, 24(1), 31-47.

Leenheer, J., Van Heerde, H. J., Bijmolt, T. H. A., \& Smidts, A. (2007). Do loyalty programs really enhance behavioral loyalty? An empirical analysis accounting for self-selecting members. International Journal of Research in Marketing, 24(1), 31-47.

Leventhal, R. C., \& Zineldin, M. (2006). The royalty of loyalty: CRM, quality and retention. Journal of Consumer Marketing.

Lewis, M. (2004). The influence of loyalty programs and short-term promotions on customer retention. Journal of Marketing Research, 41(3), 281-292.

Meyer-Waarden, L. (2007). The effects of loyalty programs on customer lifetime duration and share of wallet. Journal of Retailing, 83(2), 223-236.

Mimouni-Chaabane, A., \& Volle, P. (2010). Perceived benefits of loyalty programs: Scale development and implications for relational strategies. Journal of Business Research, 63(1), 32-37.

Mulhern, T., \& Duffy, D. (2004). Building loyalty at things remembered. Journal of Consumer Marketing, 21(1), 62-66.

Ngai, E. W. T., Xiu, L., \& Chau, D. C. K. (2009). Application of data mining techniques in customer relationship management: A literature review and classification. Expert Systems with Applications, 36(2), 2592-2602.

Noe, R. A., Hollenbeck, J. R., Gerhart, B., \& Wright, P. M. (2017). Human resource management: Gaining a 
competitive advantage. McGraw-Hill Education New York, NY.

Nunnally, J. C., \& Bernstein, I. H. (1978). Psychometric theory.

Omar, N. A., Alam, S. S., Aziz, N. A., \& Nazri, M. A. (2011). Retail loyalty programs in Malaysia: The relationship of equity, value, satisfaction, trust, and loyalty among cardholders. Journal of Business Economics and Management, 12(2), 332-352.

Powell, J. R. (2009, July 2). Methods and systems for applying a rewards program promotion to payment transactions. Google Patents.

Pritchard, M. P., \& Negro, C. M. (2001). Sport loyalty programs and their impact on fan relationships. International Journal of Sports Marketing and Sponsorship, 3(3), 64-85.

Rehnen, L. M. (2016). Exit strategies of loyalty programs. Jbm-Journal of Business Market Management, 9(1), 564-596.

Rigby, D. K., Reichheld, F., \& Dawson, C. (2003). Winning customer loyalty is the key to a winning CRM strategy. Ivey Business Journal, 67(4), 1.

Rigby, D. K., Reichheld, F. F., \& Schefter, P. (2002). Avoid the four perils of CRM. Harvard Business Review, 80(2), 101-109.

Ringle, C. M., Wende, S., \& Will, A. (2005). SmartPLS 2.0 (Beta). Hamburg. Available in Http://Www. Smartpls. De.

Salloum, S. A., Al-Emran, M., Shaalan, K., \& Tarhini, A. (2018). Factors affecting the E-learning acceptance: A case study from UAE. Education and Information Technologies. https://doi.org/https://doi.org/10.1007/s10639-018-9786-3

Salloum, S A, \& Shaalan, K. (2018). Investigating students' acceptance of e-learning system in higher educational environments in the UAE: Applying the extended technology acceptance model (TAM). The British University in Dubai.

Salloum, Said A, \& Shaalan, K. (2018). Adoption of E-Book for University Students. International Conference on Advanced Intelligent Systems and Informatics, 481-494. Springer.

Senapathi, M., \& Srinivasan, A. (2014). An empirical investigation of the factors affecting agile usage. Proceedings of the 18th International Conference on Evaluation and Assessment in Software Engineering, 10. ACM.

Sharp, B., \& Sharp, A. (1997). Loyalty programs and their impact on repeat-purchase loyalty patterns. International Journal of Research in Marketing, 14(5), 473-486.

Shugan, S. M. (2005). Brand loyalty programs: are they shams? INFORMS.

Skogland, I., \& Siguaw, J. A. (2004). Are your satisfied customers loyal? Cornell Hotel and Restaurant Administration Quarterly, 45(3), 221-234.

Smith, E. R. (2000). E-loyalty: How to keep customers coming back to your website. HarperInformation.

Uncles, M. D., Dowling, G. R., \& Hammond, K. (2003). Customer loyalty and customer loyalty programs. Journal of Consumer Marketing, 20(4), 294-316.

Verhoef, P. C., Lemon, K. N., Parasuraman, A., Roggeveen, A., Tsiros, M., \& Schlesinger, L. A. (2009). Customer experience creation: Determinants, dynamics and management strategies. Journal of Retailing, 85(1), 31-41.

Warrick, P. S., Levy, A., Carriere, L. M., Ziebart, D. T., Kullos, J. A., Fontes, D., \& MacMillan, A. T. (2015, May 19). Custom-tailored entertainment experience for user identified by different loyalty program user identifiers at different hospitality locations. Google Patents.

Wegner, B., \& Wegner, R. (2013, February 7). System for an integrated multi-vendor customer loyalty and targeted marketing program and method for its use. Google Patents.

Wendlandt, M., \& Schrader, U. (2007). Consumer reactance against loyalty programs. Journal of Consumer Marketing, 24(5), 293-304.

Yi, Y., \& Jeon, H. (2003). Effects of loyalty programs on value perception, program loyalty, and brand loyalty. Journal of the Academy of Marketing Science, 31(3), 229-240.

Yukl, G. (2008). How leaders influence organizational effectiveness. The Leadership Quarterly, 19(6), 708722.

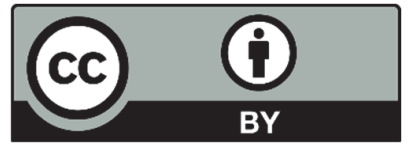

(C) 2020 by the authors; licensee Growing Science, Canada. This is an open access article distributed under the terms and conditions of the Creative Commons Attribution (CC-BY) license (http://creativecommons.org/licenses/by/4.0/). 